\title{
ЛІКУВАННЯ ОПІКОВИХ РАН ІЗ ВИКОРИСТАННЯМ КСЕНОТРАНСПЛАНТАНТІВ, НАСИЧЕНИХ НАНОКРИСТАЛАМИ СРІБЛА
}

\author{
Лікування опікових ран із використанням \\ ксенотрансплантантів, насичених нанокристалами \\ срібла

\section{С. Й. Запорожан, Н. В. Тузюк} \\ Тернопільський національний медичний університет \\ імені І. Я. Горбачевського МОЗ України
}

Резюме. На сьогодні частота опікових травм у розвинутих країнах світу сягає 1:1 тис. населення. Так, за даними Американської опікової асоціації щорічно майже 200 тис. людей отримують опіки, половині з них необхідна госпіталізація, а приблизно у 5 тис. пацієнтів опікова травма закінчується летально. При опіковій травмі залишається актуальною проблема відновлення цілості шкірного покриву при глибоких та великих за площею опіках. Протягом тривалого часу лікарі-комбустіологи різних країн світу запропонували різні методи аутодермопластики, а для тимчасового закриття опікових ран - синтетичні замінники икіри, дермальні еквіваленти, ксенотрансплантати. Однак незважаючи на досягнуті успіхи у лікуванні опікових ран, розробляються нові підходи з використанням ксенотрансплантатів із насиченням їх нанокристалами срібла.

Мета дослідження - вивчити вплив використаних ксенотрансплантатів, насичених нанокристалами срібла, на перебіг ранового процесу в пацієнтів з опіковими ранами різного ступеня тяжкості та площі ураження.

Матеріали і методи. В основу роботи покладено результати аналізу лікування 155 хворих із опіковими травмами, які перебували на стаціонарному лікуванні в Центрі термічної травми та пластичної хірургії комунального некомерційного підприємства «8 міська клінічна лікарня м. Львова» з 2017 до 2021 р. Протягом дослідження пацієнти отримували адекватну стаціонарну допомогу, під час лікування застосовували операційні та консервативні методи. Після виписки із стаціонару здійснювалися динамічні спостереження за ними протягом 6 місяців. В обстеженні пацієнтів використовували лабораторні клінічні та біохімічні, мікробіологічні та морфологічні методи дослідження. Для діагностики глибини дермальних опіків застосовували дистанційний безконтактний метод термографрії при допомозі медичного тепловізора ULIRVIZION T1-120.

Результати. Серед пацієнтів з опіковою травмою чоловіків було 102 (66 \%), з них у віці 20-59 років 84 пацієнти (54\%), жінок - 53 особи (34\%), з них 118 пацієнток у віці 20-50 років (76 \%). Найстарший пацієнт був у групі
Treatment of burns using xenotransplants, saturated with nanocrystals of silver

S. Y. Zaporozhan, N. V. Tuzyuk

I. Horbachevsky Ternopil National Medical University

e-mail: zaporozhan@tdmu.edu.ua

Summary. Today, the frequency of burns in the developed world reaches 1: 1 thousand people. Thus, according to the American Burn Association, nearly 200.000 people are burnt each year. Half of them need hospitalization, and approximately 5.000 patients end up in fatal burns. In case of burn, the problem of restoring the integrity of the skin in deep and large burns remains relevant. For a long time, combustiologists around the world have proposed various methods of autodermoplasty, and for the temporary closure of burns - synthetic skin substitutes, dermal equivalents, xenografts. However, despite the progress made in the treatment of burns, new approaches are being developed using xenografts with their saturation with silver nanocrystals.

The aim of the study - to analyze the effect of used xenografts saturated with silver nanocrystals on the course of the wound process in patients with burns of varying severity and area of the lesion.

Materials and Methods. The work is based on the analysis of treatment of 155 patients with burns who were hospitalized at the Center for Thermal Trauma and Plastic Surgery of the Municipal Non-profit Enterprise " Lviv City Clinical Hospital No. 8" from 2017 to 2021. During the study, patients received adequate inpatient care. Surgical and conservative methods were used during treatment. After discharge of patients, dynamic observations were performed for 6 months. Laboratory clinical and biochemical, microbiological and morphological research methods were used in the examination of patients. To diagnose the depth of dermal burns remote non-contact method of thermography was used with a help of a medical thermal imager ULIRVIZION T1-120.

Results. Among patients with burns, there were 102 men (66 \%), of whom 84 patients (54\%) aged 20-59, 53 women (34\%), of whom 118 patients aged 20-50 (76\%). The oldest patient was in the group of women aged 90 (0.64\%). Of those hospitalized in the Center for Thermal Trauma and Plastic Surgery, 41 patients (26\%) were referred from the surgical departments of the Central Distric Hospital, 19 patients (12\%) from the surgical departments of other 
жінок у віці 90 років (0,64 \%). з числа госпіталізованих у Центр термічної травми та пластичної хірургії 41 особу (26 \%) направили з хірургічних відділень ЦРЛ, 19 пацієнтів (12 \%) - із хірургічних відділень інших лікувальних закладів, 58 (38 \%) - госпіталізовані каретою екстреної допомоги, а 37 осіб (24 \%) самостійно звернулись у приймальне відділення. За локалізацією опікові рани діагностовано на стопах у 5 пацієнтів (3,72\%), на тулубі - в 12 (7,7\%), на плечовому поясі, верхній кінцівці (кінцівках) - у 14 (9,0 3 \%), на зап'ясті, кисті (кистях) - в 15 (9,7 \%), на голові (uиi) - у 20 пацієнтів (12,9\%), на кульшових суглобах, стегнах та гомілках - в 37 (23,9\%), на декількох частинах тіла - у 52 (33,55 \%). За глибиною ураження опікових ран найбільше пацієнтів спостерігали з ІІАВ ступенем у 57 осіб (36,8 \%), серед яких переважали чоловіки у віці 20-59 років - 40 (25,8\%). У 40 осіб (25,8 \%) спостерігали I-IIA ступені ураження, серед яких переважали особи працездатного віку (20-59 років) - 33 (21,3 \%), 36 (23,2 \%) із IIB-III ступенями ураження, а у 22 пацієнтів (14,2 \%) - тяжкий ступінь ураження. За площею опікової поверхні частіше спостерігали малі (до $10 \%)$ - у 111 пацієнтів (71,6 \%), серед яких було 83 пацієнти (53,6 \%) у віці 20-59 років, помірні (11-39\%) - у 33 (21,3\%), поширені (40 \% і більше ураження) - в 11 (7,1\%).

Висновки. Найчастіше з опіковою травмою на стаціонарному лікуванні перебували чоловіки та жінки у віці 20-59 років, працездатного віку - 118 пацієнтів (76 \%). У комплексному лікуванні дермальних опіків IIIA, II-III ступенів тяжкості з площами уражень до 10; 10-29; 30-49 \% рекомендовано використовувати клапті ксенотрансплантатів, насичені нанокристалами срібла, що значно скорочує середню тривалість лікування хворих у стаціонарі.

Ключові слова: термічний опік; площа опікової поверхні; глибина ураження; локалізація опікової рани.

\section{ВСТУП}

На сьогодні частота опікових травм у розвинутих країнах світу сягає 1:1 тис. населення. Так, за даними Американської опікової асоціації щорічно майже 200 тис. людей отримує опіки, половині з них необхідна госпіталізація, а приблизно у 5 тис. пацієнтів опікова травма закінчується летально.

У Великобританії опіки отримують щорічно близько 250 тис. людей, з яких 175 тис. осіб отримують екстрену стаціонарну допомогу, а 4300 осіб померли. В Україні щорічно звертаються за екстреною медичною допомогою близько 80 тис. пацієнтів з опіковими травмами. При цьому одним із патогенетичних чинників летальності серед хворих 3 опіковими ранами $€$ ендогенна інтоксикація на тлі опікового шоку.

При опіковій травмі залишається актуальною проблема відновлення цілості шкірного покриву при глибоких та великих за площею опіках. Тривалість перебігу опікової хвороби залежно від ступеня тяжкості триває в середньому від 15 діб medical institutions, 58 patients (38\%) were hospitalized by ambulance, and 37 people (24\%) applied to the admission department on their own. By localization, burns were diagnosed on the feet of 5 patients (3.72\%), on the torso - in 12 (7.7\%), on the shoulder girdle, upper limb (limbs) - in 14 (9.03\%), on wrists, hands - in 15 (9.7\%), on the head (neck) - in 20 patients (12.9\%), on the hips, thighs and legs - in 37 (23.9\%), on several parts of the body - in 52 (33.55\%). In terms of the depth of burns, most patients with grade IIAB were observed in 57 people (36.8\%), among whom men aged 20-59 prevailed - 40 (25.8\%). In 40 patients (25.8\%) degrees I-IIA of lesion were observed, among whom persons of working age aged 20-59 prevailed - 33 (21.3\%), 36 (23.2\%) with degrees IIB-III of lesion, and in 22 patients (14.2\%) - severe lesions. The area of the burn surface was more often observed by small (up to $10 \%$ ) - in 111 patients ( $71.6 \%)$, among whom there were 83 patients (53.6 \%) aged 20-59, moderate (11-39\%) - in 33 (21.3\%), common (40\% or more lesions) - in 11 (7.1\%).

Conclusions. Most often, men and women aged 2059 with working burns and 118 patients (76 \%) of working age were hospitalized. In the complex treatment of dermal burns of severity degrees I-IIA, II-III with lesion areas up to $10 ; 10-29 ; 30-49 \%$ recommend the use of xenograft flaps saturated with silver nanocrystals, which significantly reduces the average duration of inpatient treatment.

Key words: thermal burns; the area of the burn surface; depth of lesion; localization of a burn.

до 2-3 місяців. За рахунок великої площі ранової поверхні організм інфікується, втрачає велику кількість білків та електролітів. Протягом тривалого часу лікарі-комбустіологи різних країн світу запропонували різні методи аутодермопластики, а для тимчасового закриття опікових ран - синтетичні замінники шкіри, дермальні еквіваленти, ксенотрансплантанти.

Однак незважаючи на досягнуті успіхи у лікуванні опікових ран, розробляються нові підходи 3 використанням ксенотрансплантатів із насиченням їх нанокристалами срібла.

Метою дослідження було вивчити вплив використаних ксенотрансплантатів, насичених нанокристалами срібла, на перебіг ранового процесу в пацієнтів з опіковими ранами різного ступеня тяжкості та площі ураження.

\section{МАТЕРІАЛИ I МЕТОДИ}

У Центр термічної травми та пластичної хірургії комунального некомерційного підприємства 
«8 міська клінічна лікарня м. Львова» 22017 до 2021 р. госпіталізовано 155 пацієнтів, зокрема 56 осіб $(36,1 \%)$ прийнято за самозвертанням у приймальне відділення, каретою швидкої допомоги було госпіталізовано 37 пацієнтів (29,3%), а 21 (13,5 \%) - за направленням сімейного лікаря.

Серед госпіталізованих з опіковою травмою у $28(18,1 \%)$ було діагностовано супутню патологію з боку бронхолегеневої системи, у 32 пацієнтів IXC (20,6 \%), в 15 (9,7 \%) - цукровий діабет, у 9 $(5,8 \%)$ - захворювання сечовидільної системи, в 4 $(2,6 \%)$ - онкологічна патологія.

За етіологічним фрактором серед госпіталізованих хворих із дермальними опіками переважали пацієнти 3 опіками рідинами 93 (60\%), а у 62 (40 \%) - опікові рани, спричинені полум'ям.

Серед 35 пацієнтів (22,6 \%), госпіталізованих у реанімаційне відділення Центру термічної травми та пластичної хірургії комунального некомерційного підприємства «8 міська клінічна лікарня м. Львова» у $27(77,1 \%)$ у віці 20-59 років було діагностовано опіковий шок середнього та тяжкого ступенів тяжкості, а у 8 пацієнтів (22,9 \%) - помірний ступінь тяжкості.

\section{РЕЗУЛЬТАТИ Й ОБГОВОРЕННЯ}

За терміновістю виконання операційних втручань серед пацієнтів з опіковою травмою, залежно від загального стану, зумовленого тяжкістю опікового шоку, наявності супутньої патології, операції проводили в екстреному, ранньому відтермінованому та пізньому відтермінованому порядках (рис.).

Екстрені операційні втручання виконували у 54 пацієнтів (34,8 \%), ранньовідтерміновані - у 43 (27,7 \%), пізньовідтерміновані - у 33 (21,3 \%), а у 25 пацієнтів $(16,1 \%)$ операційні втручання не проводили.

Із 155 пацієнтів, госпіталізованих із дермальними опіками I-IIA та IIAB ступенями тяжкості в Центр термічної травми та пластичної хірургії комунального некомерційного підприємства «8 міська клінічна лікарня м. Львова» 32017 до 2021 р. було відібрано дві групи. У першій групі - 78 осіб (50,3 \%), яким для місцевого лікування опікової рани після проведеної ранньої некректомії застовували традиційну місцеву терапію з використанням мазевих

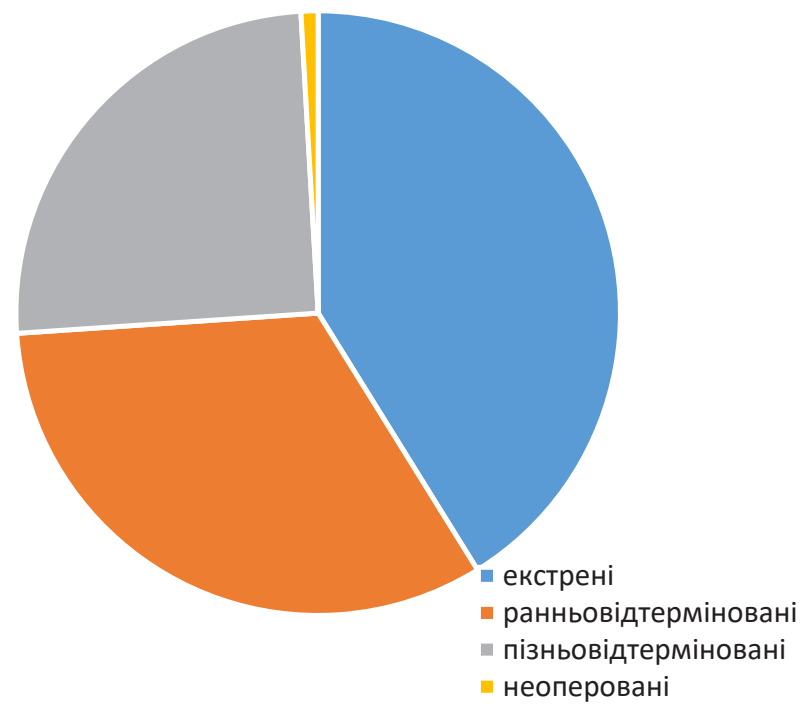

Рис. Терміновість виконання операційних втручань у пацієнтів 3 опіковою травмою (екстрені, ранньовідтерміновані, пізньовідтерміновані)

пов'язок з антисептиками. Другу групу - 77 (49,7\%) було поділено на дві підгрупи. У 42 пацієнтів (54,5 \%) після ранньої некректомії було використано поряд із загальною консервативною терапією у лікуванні опікових ран пов'язки з перфорованими ліофілізованими клаптями (табл. 1).

Частіше ліофілізовані перфоровані клапті використовували в 33 пацієнтів (78,6 \%) у віці 20-59 років, а в 36 осіб (86 \%) - 3 II та ІІА ступенями тяжкості.

У другій підгрупі другої групи у 35 пацієнтів (45,5 \%) після проведеної ранньої некректомії використовували клапті ксенотрансплантатів, насичені нанокристалами срібла (патент на корисну модель UA 102105 U від 12.10.2015 р.). Також застосовували клапті ксенотрансплантатів, насичені нанокристалами срібла, 29 пацієнтам (82,8 \%) віком 20-59 років, $26(74,3 \%)$ із IIA та IIB ступенями тяжкості.

Під час проведення клінічного дослідження результатів лікування 42 пацієнтів (54,5 \%) із дермальними опіками у першій підгрупі другої групи після проведеної ранньої некректомії виявлено, що у 13 (31 \%) із IIB-III ступенями тяжкості площа ураження становила до $10 \%$, а у 10 пацієнтів (24 \%) площа ураження була 1029 \% (табл. 2).

Таблиця 1. Рання некректомія з використанням перфорованих ліофілізованих клаптів

\begin{tabular}{l|c|c|c|c}
\hline \multirow{2}{*}{\begin{tabular}{l}
\multirow{2}{*}{ Ступінь ураження } \\
\cline { 2 - 4 }
\end{tabular}} & \multicolumn{3}{|c|}{ Вік, роки } & \multirow{2}{*}{ Усього, $\mathrm{n}(\%)$} \\
\cline { 2 - 4 } & $\mathrm{20-59}$ & $60-74$ & $\mathrm{n}(\%)$ & \\
\hline $\mathrm{II}$ & $16(38,1)$ & $\mathrm{n}(\%)$ & $1(2,4)$ & $21(50)$ \\
\hline IIA & $13(31)$ & $4(9,5)$ & - & $15(36)$ \\
\hline УС & $4(9,5)$ & $2(4,8)$ & - & $6(14,3)$ \\
\hline
\end{tabular}


Таблиця 2. Тривалість лікування пацієнтів із дермальними опіками з використанням перфорованих ліофілізованих клаптів

\begin{tabular}{|c|c|c|c|c|c|}
\hline \multirow{3}{*}{ Ступінь ураження } & \multicolumn{4}{|c|}{ Площа, \% } & \multirow{3}{*}{ Усього } \\
\hline & до 10 & $10-29$ & $30-49$ & більше 50 & \\
\hline & $\mathrm{n}(\%)$ & n (\%) & $\mathrm{n}(\%)$ & n (\%) & \\
\hline I-IIA & $5(11,9)$ & $3(7,1)$ & $6(14,2)$ & $2(5)$ & 16 \\
\hline IIB-III & $13(31)$ & $10(24)$ & $2(5)$ & $1(2,4)$ & 26 \\
\hline Усього & $18(43)$ & $13(31)$ & $8(19)$ & $3(7,1)$ & 42 \\
\hline
\end{tabular}

При лікуванні пацієнтів із дермальними опіками I-IIA, IIB-III ступенів тяжкості з використанням клаптів ксенотрансплантатів, насичених нанокристалами срібла, ми відмітили, що з 35 пацієнтів у 10 із IIB-III ступенями тяжкості площа ураження становила 10-49 \% (28,5\%), а в 7 осіб (20 \%) площа ураження була 30-49 \% (табл. 3).

При порівнянні середньої тривалості ліжко-днів перебування пацієнтів першої та другої підгруп другої групи в Центрі термічної травми ми встановили, що ліжко-день для хворих першої підгрупи другої групи 3 I-IА ступенями тяжкості з площею до 10 \% становив 8 днів, у таких же хворих другої підгрупи другої групи із використанням пов'язок, насичених нанокристалами срібла, становив 6 днів. Для хворих з опіками IIB-III ступенів тяжкості з площею уражень до 10 \% 13 ліжко-днів. Разом з тим для пацієнтів другої групи другої підгрупи із використанням пов'язок, насичених нанокристалами срібла, - 11 ліжко-днів. Для хворих із I-IIA ступенями тяжкості та з площею до 30 \% ceредня тривалість лікування в стаціонарі становила
13 ліжко-днів. Така ж тривалість лікування була характерна серед пацієнтів із використанням пов'язок, насичених нанокристалами срібла. У хворих із IIB-III ступенями тяжкості з площею уражень до 30 \% середня тривалість лікування в стаціонарі становила 25 ліжко-днів. Разом з тим у другій підгрупі другої групи пацієнтів із використанням пов'язок, насичених нанокристалами срібла, такий показник становив 19 ліжко-днів. У хворих I-II ступенів тяжкості з опіками 50 \% площі ураження середня тривалість лікування в стаціонарі становила 21 ліжко-день, тоді як у такої ж групи пацієнтів із використанням пов'язок, насичених нанокристалами срібла, середня тривалість перебування в стаціонарі була 19 ліжко-днів. Серед хворих із IIAB-III ступенями тяжкості з площею ураження до 50 \% середня тривалість перебування в стаціонарі становила 40 ліжко-днів, тоді як у другій підконтрольній підгрупі другої групи пацієнтів з використанням пов'язок насичених нанокристалами срібла аналогічний показник становив 33 ліжко-днів (табл. 4).

Таблиця 3. Тривалість лікування пацієнтів із дермальними опіками з використанням клаптів ксенотрансплантатів, насичених нанокристалами срібла

\begin{tabular}{|c|c|c|c|c|c|}
\hline \multirow{3}{*}{ Ступінь ураження } & \multicolumn{4}{|c|}{ Площа ураження, \% } & \multirow{3}{*}{ Усього } \\
\hline & до 10 & $10-29$ & $30-49$ & більше 50 & \\
\hline & $\mathrm{n}(\%)$ & $\mathrm{n}(\%)$ & $\mathrm{n}(\%)$ & $\mathrm{n}(\%)$ & \\
\hline I-IIA & $10(28,5)$ & $7(20)$ & $3(8,6)$ & $2(5,7)$ & 22 \\
\hline IIB-III & $2(5,7)$ & $6(17,1)$ & $4(11,4)$ & $1(2,8)$ & 13 \\
\hline Усього & $12(34)$ & $13(37)$ & $7(20)$ & $3(8,6)$ & 35 \\
\hline
\end{tabular}

Таблиця 4. Середні терміни перебування у стаціонарі пацієнтів із дермальними опіками з використанням перфорованих ліофілізованих клаптів та ксенотрансплантатів, насичених нанокристалами срібла

\begin{tabular}{|c|c|c|c|c|c|c|}
\hline \multirow{3}{*}{ Ступінь ураження } & \multicolumn{6}{|c|}{ Площа, \% } \\
\hline & \multicolumn{2}{|c|}{ до 10} & \multicolumn{2}{|c|}{ до 30} & \multicolumn{2}{|c|}{ до 50} \\
\hline & ліоф. кс. & KC. $\mathrm{Ag}$ & ліоср. кс. & KC. $\mathrm{Ag}$ & ліоф. кс. & KC. $\mathrm{Ag}$ \\
\hline I-IIA & 8 & 6 & 13 & 13 & 21 & 19 \\
\hline IIB-III & 13 & 11 & 25 & 19 & 40 & 33 \\
\hline Усього & 21 & 17 & 38 & 32 & 61 & 52 \\
\hline
\end{tabular}

\section{ВИСНОВКИ}

У комплексному лікуванні дермальних опіків I-IIA, II-III ступенів тяжкості з площами уражень до 10; 10-29; 30-49 \% рекомендовано викорис- товувати клапті ксенотрансплантатів, насичених нанокристалами срібла, що значно скорочує середню тривалість лікування хворих у стаціонарі (на 15,8\%).
$3(9), 2021$ 


\section{СПИСОК ЛІТЕРАТУРИ}

1. Комбустіологія : підручник / [Е. Я. Фісталь, Г. П. Козинець, Г. Є. Самойленко та ін.]. - К. : Інтерлік, 2004. - 184 с.

2. Патент на корисну модель UA 102105 U від 12.10.2015p. Спосіб лікування ран з використанням ліофрілізованих ксенодермотрансплантантів, насичених нанокристалами срібла.

3. Тузюк Н. В. Використання дистанційного методу термограсрії для діагностики / С. Й. Запорожан, М.Т.Гук // Шпитальна хірургія. Журнал імені Л.Я. Ковальчука. 2021. - № 3.

\section{REFERENCES}

1. Fistal EYa, Kozynets HP, Samoilenko H.Ye. Combustiology: a textbook. [Комбустіологія: підручник] Kyiv: Interlik; 2004. Ukrainian.

2. Patent for utility model UA 102105 U dated October 12, 2015. A method of treating wounds using lyophilized xenodermotransplants saturated with silver nanocrystals. Ukrainian.

3. Tuziuk NV, Huk MT. [Using the remote method of thermography for diagnosis]. Shpyt khirur. Zhurn im. LYa Kovalchuka. 2021;3. Ukrainian.
4. Використання ліофрілізованих ксенотрансплантатів у комбустіології : метод. реком. / В. В. Бігуняк, М. Ю. Повстяний, В. І. Нагайчук, Н. В. Гуда. - Тернопіль, 2003. $-21 \mathrm{c}$.

5. Гуда Н. В. Обгрунтування використання фоотомодифікованих ксенотрансплантантів у комплексному лікування опікових хворих : дис. канд. мед. наук / Н. В. Гуда. - Тернопіль, 2006. - 22 с.

4. Bihuniak VV, Povstianyi MYu, Nahaichuk VI, Huda NV. Use of lyophilized xenografts in combustiology. Guidelines. [Використання ліофілізованих ксенотрансплантантів у комбустіології. Методичні рекомендації] Ternopil; 2003. Ukrainian.

5. Huda NV. Rationale for the use of photomodified xenografts in the complex treatment of burn patients. Candidate's thesis. Ternopil; 2006. Ukrainian.

Отримано 05.08.21 